\title{
ISOTOPES' RADIOCARBON MEASUREMENTS XI
}

\section{JAMES BUCKLEY}

Teledyne Isotopes, Westwood, New Jersey

\section{INTRODUCTION}

This date list includes samples dated from 1968 through 1972. The method of analysis is described in R, 1968, v 10, p 246 and 1970, v 12, p 87. The ages are calculated with the 5568 year half-life without application of any corrections. The NBS oxalic acid standard is used as the modern reference. Errors $( \pm 1 \sigma)$ include standard deviations for sample counts, background and modern standard.

\section{ACKNOWLEDGMENTS}

I wish to thank $\mathrm{J}$ Bonicos for his technical assistance and $\mathrm{H}$ Principe for her help in the preparation of the manuscript.

\section{SAMPLE DESCRIPTIONS}

I. GEOLOGIC SAMPLES

\section{A. United States}

I-6340. HR-21, calcite

$$
\begin{gathered}
6380 \pm 125 \\
4430 \mathrm{BC} \\
\delta^{13} C=-8.6 \% \text { o }
\end{gathered}
$$

Calcite cement from kame terrace $7 \mathrm{~km}$ SW of Belvidere on Hutchinson $\mathrm{Rd}\left(40^{\circ} 47^{\prime} \mathrm{N}, 75^{\circ} 07^{\prime} \mathrm{W}\right)$, New Jersey. Coll and subm 1972 by $\mathrm{M}$ Pendleton, Dept of Geol, Rutgers Univ, New Brunswick. Sample found coating gravel at $2 \mathrm{~m}$ depth. Comment (MP): date obtained to determine if Pleistocene gravel is being cemented with contemporary calcium carbonate.

\section{I-3665. No. 404-74A Winter Gulf site}

$12,730 \pm 230$

Wood from Lake Erie Lowland, $10 \mathrm{~km} \mathrm{~S}$ of village of North Collins, W edge of US Rte $62\left(42^{\circ} 33^{\prime} 40^{\prime \prime}\right.$ N, $\left.78^{\circ} 56^{\prime} 02^{\prime \prime} \mathrm{W}\right)$, New York. From $178 \mathrm{~cm}$ depth in peat overlain by alluvium (Calkin \& McAndrews, 1969; Calkin, 1970). Coll and subm 1971 by P E Calkin.

\section{I-8022. No. 404-74AA Winter Gulf site}

Same as above at $164 \mathrm{~cm}$ depth.

\section{Van Norman Reservoir series, California}

Samples from Pleistocene-Holocene surficial deposits of fluvial origin, Van Norman Reservoir ( $34^{\circ} 17^{\prime} 39^{\prime \prime} \mathrm{N}, 118^{\circ} 28^{\prime} 39^{\prime \prime} \mathrm{W}$ ), San Fernando, Los Angeles Co, California (Yerkes et al, 1973). Coll 1972 by J D Sims, V A Frizzell, Jr, E Helley, and J B Wallace; subm 1972 by J D Sims, US Geol Survey, Menlo Park, California. 
I-6695. U.210

$$
1700 \pm 90
$$

AD 250

Carbonized wood fragments from Unit 3, crossbedded sand and gravel (Yerkes et al, 1973).

I-6696. U-214

$355 \pm 90$

Wood in Unit 1 composed of gravel with subordinate amounts of interbedded sand, peaty sand, and silt. The sand and silt units occupy abandoned stream channels cut into underlying gravel.

\section{I.6697. U-220}

$430 \pm 85$

Wood from interbedded silt and sand in upper $1 / 3$ of Unit 1 .

\section{I-6698. U-221}

Wood from upper $1 / 3$ to $1 / 2$ of Unit 1 .

I-6715. U-16A

$285 \pm 85$ AD 1665

$$
\begin{array}{r}
660 \pm 95 \\
\text { AD } 1290
\end{array}
$$

Wood from carbonaceous sandy silt in SE wall (Yerkes et al, 1973, fig 4). Correlated with Unit 2.

I-6716. U-222

AD 1665

$285 \pm 85$

Peaty sandy silt that fills channel-like depressions of Unit 1 .

\section{I-6717. U-91}

AD 1120

$$
830 \pm 90
$$

Carbonaceous sandy silt that grades $\mathrm{W}$-ward into peaty silt of locality U-222. Comment (JDS): date may be older than true age because a soil horizon to the $\mathrm{E}$ on Unit 3 contains older carbonaceous material that may have been added to the sedimentation slide from which U-91 was coll.

\section{I-6944. U-13 TOP}

$2715 \pm 90$ $765 \mathrm{BC}$

Carbonaceous sand and silt from Unit 4. Comment (JDS): unit represents swampy wet condition that promoted abundant plant growth in an abandoned channel. Samples U13A and U13B from the base of this unit gave unpub ages of 8820 and 9270 yr BP indicating that wet conditions persisted for at least $6000 \mathrm{yr}$.

\section{Fourth of July Valley Bog series, Colorado}

Sedge peat from $\mathrm{N}$ fork Middle Boulder Creek $\left(40^{\circ} 00^{\prime} 30^{\prime \prime} \mathrm{N}, 105^{\circ}\right.$ $40^{\prime} 20^{\prime \prime} \mathrm{W}$ ), Boulder Co, Colorado. From 46 to $47 \mathrm{~cm}$ depth, overlies outwash from Early Neoglacial moraines upvalley. Coll 1970 and subm 1971 by $\mathrm{J}$ B Benedict.

\section{I-5452. NaOH-insoluble}


I-5453. NaOH-soluble

General Comment (JBB): provides minimum age for early Neoglacial advance and for dissection of late Pinedale outwash in valley (Benedict, 1973b.)

\section{Satanta Peak Bog series, Colorado}

Samples from lateral bog between Santanta Peak and Early Holocene moraine damming Caribou Lake (40 $01^{\prime} 25^{\prime \prime} \mathrm{N}, 105^{\circ} 41^{\prime} 00^{\prime \prime} \mathrm{W}$ ), Grand Co, Colorado. Coll 1971 and 1972; subm 1972 by J B Benedict.

\section{I-6335. No. 1}

$9915 \pm 165$

Fibrous sedge peat, $\mathrm{NaOH}$-insoluble, from 76 to $77 \mathrm{~cm}$ depth, above outwash from Early Holocene moraine damming Caribou Lake.

I-6336. No. 2

$9700 \pm 215$

Same as I-6335.

$7750 \mathrm{BC}$

I-6337. No. 3

$6015 \pm 115$

4065 BC

Fibrous sedge peat, $\mathrm{NaOH}$-insoluble, from 21 to $22 \mathrm{~cm}$ depth, directly beneath erosion surface overlain by thin layer of muck containing irregular sand lenses and stones.

I-6380. No. 4

$2255 \pm 95$

$\mathbf{3 0 5} \mathbf{B C}$

Muck, NaOH-insoluble, from 18 to $20 \mathrm{~cm}$ depth, directly overlying zone containing sand lenses and stones.

I-6520. No. 5

$9200 \pm 135$

7250 BC

Wood from 63 to $66 \mathrm{~cm}$ depth. Log directly upon lowermost continuous clastic layer, overlain by fibrous peat.

I-6788. No. 6

$7440 \pm 125$ 5490 BC

Peat, NaOH-insoluble, from 66 to $67 \mathrm{~cm}$ depth, directly above micaceous silt layer.

\section{I-6789. No. 7}

$7900 \pm 130$

5950 BC

Muck, NaOH-insoluble, from 68 to $69 \mathrm{~cm}$ depth, directly beneath micaceous silt layer.

General Comment (JBB): I-6335 and -6336 provide minimum age for deposition of moraine damming Caribou Lake. I-6788 and -6789 bracket deposition of clastic layer thought to reflect slopewash erosion of surrounding slopes. I-6380 and -6337 loosely bracket early Neoglacial erosion, followed by ice-rafting or avalanche deposition on floor of bog. I-6520 is 
stratigraphically out of place, and may represent older log redeposited in bog (Benedict, 1973b).

\section{Caribou Lake Moraine Bog series, Colorado}

Muck from Kettle Bog on Early Holocene moraine $200 \mathrm{~m}$ SE of Caribou Lake outlet $\left(40^{\circ} 01^{\prime} 15^{\prime \prime} \mathrm{N}, 105^{\circ} 40^{\prime} 45^{\prime \prime} \mathrm{W}\right)$, Grand Co, Colorado. Coll 1971 and subm 1972 by J B Benedict.

\section{I-6381. A 1}

$1390 \pm 95$

From 27 to $28 \mathrm{~cm}$ depth, $\mathrm{NaOH}$-insoluble fraction, immediately above micaceous silt layer.

\section{I-6382. A 2}

$$
1505 \pm 95
$$

AD 445

From 29 to $30 \mathrm{~cm}$ depth, $\mathrm{NaOH}$-insoluble fraction, immediately below micaceous silt layer. Comment (JB): I-6381 and -6382 bracket deposition of clastic layer near center of bog. Silt grades into gravelly sand and was probably deposited during interval of slopewash erosion on surrounding morainal ridges.

\section{I-6383A. A 3}

From 54 to $57 \mathrm{~cm}$ depth, basal. NaOH-soluble fraction.

\section{I-6383B. A 4}

$6200 \pm 105$

4250 BC

From 54 to $57 \mathrm{~cm}$ depth, basal. $\mathrm{NaOH}$-insoluble fraction. Comment (JB): I-6383A and -6383B provide minimum ages for deposition of moraine but may be inadequate (Mickelson \& Borns, 1972).

\section{Arapaho Cirque series, Colorado}

Samples from S fork, N Boulder Creek, Boulder Co, Colorado.

\section{I-6986. Arapaho I}

$3865 \pm 100$

1915 BC

Proglacial lake sediments from former drainage channel across crest of early Neoglacial terminal moraine $\left(40^{\circ} 01^{\prime} 30^{\prime \prime} \mathrm{N}, 105^{\circ} 37^{\prime} 50^{\prime \prime} \mathrm{W}\right)$, depth 119 to $128 \mathrm{~cm}$. Lake sediments overlie till and are buried by alluvial fan deposits and windblown sand. Coll 1972 and subm 1973 by J B Benedict. Comment (JBB): provides close minimum age for second advance of early Neoglacial ice in Arapaho Cirque.

\section{I-3858. Arapaho II}

$955 \pm 95$

Plant fragments, pollen, and insect remains melted from ablation surface in glacial-ice core of rock glacier $\left(40^{\circ} 01^{\prime} 13^{\prime \prime} \mathrm{N}, 105^{\circ} 38^{\prime} 27^{\prime \prime} \mathrm{W}\right)$. Ice overlain by 85 to $95 \mathrm{~cm}$ of blocky rubble. Sampled $10 \mathrm{~m}$ upvalley from I-2562 (1000 \pm 90 вP; R, 1969, v 11, p 53-105). Coll 1967 by J Benedict and B Olson; subm 1968 by J Benedict. 


\section{I-6791. Arapaho III}

Mucky sedge peat, NaOH-insoluble, from 70 to $71 \mathrm{~cm}$ at base of bog $\left(40^{\circ} 01^{\prime} 30^{\prime \prime} \mathrm{N}, 105^{\circ} 37^{\prime} 45^{\prime \prime} \mathrm{W}\right)$, between early neoglacial lateral moraine and S valley wall. Coll and subm 1972 by J B Benedict. Comment (JBB): provides close minimum age for first and most extensive advance of early Neoglacial ice in Arapaho Cirque (Benedict, 1973b).

\section{I-6790. Arapaho IV}

Same as I-6791.

\section{I-6228. Mud Creek local biota}

Wood from Bennett Quad NW1/4 NW1/4 sec 7 T79N RIE $\left(41^{\circ} 39^{\prime}\right.$ $55^{\prime \prime}$ N, $90^{\circ} 53^{\prime} 45^{\prime \prime}$ W), Cedar Co, Iowa. Local site No. MC7NWC. From upper $30 \mathrm{~cm}$ of fossiliferous sand exposed in bank of Mud Creek. Coll 1971 by T L Kramer, subm 1971 by H A Semken, Dept Geol, Univ Iowa, Iowa City. Comment (HAS): assoc pollen and microvertebrates suggest cooler more mesic climate for E-central Iowa $6000 \mathrm{yr}$ ago.

\section{I-7088. Toyah Mammoth site, Texas}

$12,140 \pm 140$

\section{0,190 BC}

Shells of Anodonta grandis, freshwater unionacean mussel, S edge of village of Toyah $\left(31^{\circ} 19^{\prime} 40^{\prime \prime} \mathrm{N}, 103^{\circ} 48^{\prime} 9^{\prime \prime} \mathrm{W}\right)$, Reeves Co, Texas. From W side of short arroyo entering Toyah Creek from S; $61 \mathrm{~m} \mathrm{SW}$ of bridge on abandoned road leading S to Saragosa. Coll 1972 and subm 1973 by A L Metcalf, Dept Biol Sci, Univ Texas, El Paso, Texas. Comment (ALM): shells occur in lower $1 / 3$ of bank $3 \mathrm{~m}$ high, mammoth skull removed at same level.

\section{B. Canada}

\section{Chicoutimi Terrace series, Quebec, Canada}

Samples from a clay terrace produced by landslide alongside Saguenay R (48 $\left.26^{\prime} 55^{\prime \prime} \mathrm{N}, 71^{\circ} 08^{\prime} 10^{\prime \prime} \mathrm{W}\right)$, Chicoutimi, Quebec. Coll and subm 1971 by J C Dionne, Laurentian Forest Research Centre.

\section{I-6116. Chicoutimi Terrace 1} $435 \pm 90$

Pinus banksiana with 22 growth rings, from $2 \mathrm{~m}$ below terrace surface. Comment (JCD): trunk was buried in clay during a landslide and is considered appropriate for dating the landslide (Lasalle \& Chagnon, 1968).

\section{I-6117. Chicoutimi Terrace 2} $500 \pm 90$

Organic debris from $3 \mathrm{~m}$ depth in disturbed marine clay. Comment (JCD): date considered maximum for landslide. 


\section{France}

\section{Condat Tufa series, Dordogne, France}

Tufa exposed in a quarry $1 / 2 \mathrm{~km} \mathrm{SE}$ of Condat $\left(45^{\circ} 07^{\prime} 00^{\prime \prime} \mathrm{N}, 01^{\circ}\right.$ $\left.14^{\prime} 16^{\prime \prime} \mathrm{E}\right)$, Dordogne, France. Tufa rests on Jurassic limestone and is being measured both in its own right and also to obtain a limiting date for the overlying Montignac formation (Vita-Finzi, 1974). Coll and subm 1972 by C Vita-Finzi, Univ Coll, London, England.

\section{I-6945. JD-21}

$$
\begin{aligned}
& 12,890 \pm 175 \\
& 10,940 \mathrm{BC}
\end{aligned}
$$

From contact between Condat Tufa and overlying Montignac formation. Comment $(\mathrm{CV})$ : high porosity, position at top of tufa and evidence of recrystallization leads to rejection of this date.

\section{I-6946. JD-22}

$12,320 \pm 175$

Same as I-6945. Comment (CV): presence of rhombs of dolomite and secondary calcitic cementation leads to rejection of this date.

\section{I-6795. JD-2}

$21,730 \pm 410$

$$
19,780 \text { вC }
$$

From $2 \mathrm{~m}$ below contact surface. Comment (CV): sample of compact tufa rich in algal material. Date provisionally accepted for closing stages of tufa deposition. Archaeologic evidence supports implication that the overlying Montignac Formation does not antedate 21,730 BP.

\section{I-7472. JD-93}

$$
25,880 \pm 650
$$

From $3 \mathrm{~m}$ below contact.

\section{I.7473. JD-94}

$31,050 \div 1500$

Marl from $4 \mathrm{~m}$ below contact.

\section{I-6794. Dordogne DP-5}

$1335 \pm 90$

\section{AD 615}

Charcoal from Manaurie Valley $3 \mathrm{~km} \mathrm{NW}$ of Les Eyzies (44 $57^{\prime} 21^{\prime \prime}$ $\mathrm{N}, 01^{\circ} 00^{\prime} 05^{\prime \prime} \mathrm{E}$ ), France. From $1 \mathrm{~m}$ depth in $2 \mathrm{~m}$ thick Limeuil Alluvium. Alluvium forms younger of 2 fills in Vezere and middle Dordogne Valleys (Vita-Finzi, 1974). Coll and subm 1972 by C Vita-Finzi. Comment (CV): date supports archaeologic evidence for deposition of Limeuil Alluvium in historic time.

$$
\text { D. Asia }
$$

\section{Khumbu Glacier series, Nepal}

Samples from $\mathrm{S}$ of Khumbu Glacier terminus $\left(27^{\circ} 54^{\prime} \mathrm{N}, 86^{\circ} 49^{\prime} \mathrm{E}\right)$, Nepal. Coll 1971 and subm 1972 by J B Benedict. 


\section{I-6642. Alt 4260m}

Charcoal from 48 to $50 \mathrm{~cm}$ depth, $4 \mathrm{~cm}$ above base of mudflow fan overlying outwash sands and gravels. Outwash relates to Terrace III, 2 to $3 \mathrm{~cm}$ above modern flood plain.

\section{I-6727. Alt 4245m}

Charcoal $(45 \%)$ and soil humates $(55 \%)$ from 8 to $10 \mathrm{~cm}$ depth, at base of turf developed on outwash sands and gravels. Outwash relates to Terrace III, 2 to $3 \mathrm{~cm}$ above modern flood plain.

\section{I-6728. Alt 4235m}

Charcoal and shrub fragments from 31 to $32.5 \mathrm{~cm}$ depth, from surface of bedded outwash sands and gravels, overlain by Eolian sand. Outwash relates to Terrace II, 4 to $5 \mathrm{~cm}$ above modern flood plain.

General Comment (JBB): dated to provide control of lichen growth-rate study. Tentative growth rate for rhizocarpon geographicum in Khumbu Valley is ca $15 \mathrm{~mm} / 100 \mathrm{yr}$. Compare with B-173 $(1150 \pm 80 \mathrm{BP})$ and B-174 $(480 \pm 80$ вр) from Gorak Shep higher in the valley $(R, 1961, v 3, p 16)$.

\section{E. Malaysia}

\section{Kim Kee No. 6 mine series}

Wood from Kim Kee No. 6, an opencast tin mine in Ampang, Kuala Lumpur (3॰ $\left.09^{\prime} 30^{\prime \prime} \mathrm{N}, 101^{\circ} 44^{\prime} 40^{\prime \prime} \mathrm{E}\right)$, Selangor, Malaysia. Coll and subm 1971 by P H Stauffer, Dept Geol, Univ Malaya, Kuala Lumpur.

\section{I-6192. KL-6, UM 7869}

$$
1145 \pm 90
$$

Woody stem $10 \mathrm{~cm}$ above top of volcanic ash layer in sandy clay alluvium. Comment (PHS): date is minimum for volcanic ash thought to be from Toba in Sumatra.

\section{I-6193. KL-6, UM 7870}

From $\log 80 \mathrm{~cm}$ below volcanic ash layer in peat.

$\begin{array}{ll}\text { I-6472. KL-6, UM } 7912 & \mathbf{3 4 , 5 5 0 ~ B C} \\ \text { From } \log 20 \mathrm{~cm} \text { below volcanic ash layer. Comment } & \text { (PHS): this date }\end{array}$ and I-6193 are maximum for volcanic ash. If this ash is from Toba eruption in Sumatra, these dates indicate that event is more recent than supposed on the basis of potassium-argon determinations (Stauffer, 1971).

\section{I-6702. KL-6, UM 7952} canic ash.

\section{$33,250 \pm 1800$ 31,300 BC}

$36,500 \pm 2500$

$>39,900$ 
Wood from Lian Yap No. 1 opencast tin mine, Ulu Yam Baru $\left(3^{\circ}\right.$ $\left.25^{\prime} 42^{\prime \prime} \mathrm{N}, 101^{\circ} 39^{\prime} 54^{\prime \prime} \mathrm{E}\right)$, Selangor, Malaysia. Log from within peat lens forming part of filled channel cut into weathered alluvium. Coll 1972 by L Kian Hai; subm 1972 by P H Stauffer. Comment (PHS): date is surprising since alluvium filling channel were considered Holocene. It is possible that log was reworked from older river deposits.

II. ARCHAEOLOGIC SAMPLES

\section{A. United States}

\section{I-6730. Fralinger site, 1}

$3830 \pm 100$

$1880 \mathrm{BC}$

Charcoal from E bank of Maurice R, Port Elizabeth $\left(39^{\circ} 19^{\prime} 10^{\prime \prime} \mathrm{N}\right.$, $\left.74^{\circ} 59^{\prime} 45^{\prime \prime} \mathrm{W}\right)$, New Jersey. Coll and subm 1972 by R A Mounier, Dept Anthropol Memorial Univ, Newfoundland, Canada. From small hearth in Stratum 2. Assoc with large square stemmed projectile points and a chipped celt. Comment (RAM): sample dates early development of Late Archaic Susquehanna tradition in S New Jersey.

\section{Camelot 1 Site series}

Hearth charcoal from the Camelot No. 1 site in Otsego Co $\left(42^{\circ} 25^{\prime}\right.$ $08^{\prime \prime} \mathrm{N}, 75^{\circ} 08^{\prime} 28^{\prime \prime}$ W), New York. Coll 1971 by R Houck and R Funk; subm 1972 by R Funk.

I-6641. Loc 1, Feature 1

$3425 \pm 95$

$1475 \mathrm{BC}$

Feature from center of cluster of Frost Island artifacts, separated from some items belonging to other cultures occurring on same level. Comment (RF): date oldest available for Frost Island phase, but consistent with over-all chronology of Upper Susquehanna Valley.

\section{I-6745. Loc 2, Feature 2}

$$
1820 \pm 95
$$

Feature was basin-shaped hearth that contained an Orient Fishtail point and expected to be assoc with Transitional component. Comment $(\mathrm{RF})$ : date much younger than anticipated for Transitional component, which should be ca 1200 BC.

\section{I-6744. Camelot 2 site, New York}

Hearth charcoal from Otsego Co $\left(42^{\circ} 25^{\prime} 04^{\prime \prime} \mathrm{N}, 75^{\circ} 08^{\prime} 18^{\prime \prime} \mathrm{W}\right)$, New York. Feature from Zone D, Frost Island living floor at site, assoc with Susquehanna Broad points and soapstone. Coll 1972 by R M Houck; subm 1972 by R E Funk. Comment (REF): date very satisfactory in terms of existing chronology.

\section{Fortin site series}

Hearth charcoal from the Fortin site, a stratified floodplain site in Otsego Co $\left(42^{\circ} 27^{\prime} 10^{\prime \prime} \mathrm{N}, 75^{\circ} 00^{\prime} 57^{\prime \prime} \mathrm{W}\right)$, New York (Ritchie, 1969; Funk 
et al, 1973). Coll 1971 by B Rippeteau, R Funk, B Wellman, \& R Houch; subm 1972 by R E Funk.

I-6350. Loc 2, Feature 2

$1475 \pm 90$

Feature from Occupation 2, a Middle Woodland living floor, which produced a small non-diagnostic artifact.

I-6351. Loc 1, Feature 28

$3775 \pm 115$

From Zone 3, a Late Archaic floor, containing examples of newly defined Vestal Notched point (Funk et al, 1973). Comment (REF): date agrees with other dates for site and with general Archaic chronology for Upper Susquehanna Valley.

I-6368. Loc 1, Feature 7

$3610 \pm 95$

From Zone 3, a living floor with evidence of Late Archaic occupations id from Vestal Notched and Normanskill points. Comment (REF): date corresponds to other determinations for Normanskill points in the region (I-6739, -6732, this list) and agrees with other dates for the site.

\section{I-6369. Loc 1, Feature 25}

$3750 \pm 95$

From Zone 4, a late Archaic floor that yielded Lamoka type points. Comment (REF): date is consistent with other dates for this loc and for similar Archaic components in the Susquehanna Valley.

\section{I-6565. Loc 2, Feature 3}

$1120 \pm 90$ AD 830

Feature pertained to Occupation 3, representing a component of Kipp Island phase of Late Point Peninsula. Comment (REF): date conforms to others for Kipp Island phase.

\section{I-6566. Loc 1, Feature 22}

$3880 \pm 100$

From Zone 5, a Late Archaic midden without diagnostic artifacts. Lamoka and Lamoka-like points were recovered from overlying and underlying horizons.

$3840 \pm 100$

\section{I-6567. Loc 1, Feature 24}

From Zone 4, which yielded Lamoka type points.

$1890 \mathrm{BC}$

\section{I-6568. Loc 1, Feature 29 \\ 1-6568. Loc 1, Feature 29}

From Zone 7, basal occupation floor, which contained 2 Lamoka-like points and netsinkers. Comment (REF): date is consistent with typologic estimates and radiocarbon dates for other levels of site.

\section{I-6739. Loc 1, Feature 14.}

$3685 \pm 100$

From Zone 3, an intensively occupied area, containing Normanskill points, other side-notched points and stone tools. 


\section{I-6740. Loc 1, Feature 74}

From Zone 1B, just below plow line. Assoc with 2 Meadowood SideNotched points and 3 trianguloid cache blades. Comment (REF): date consistent with ${ }^{14} \mathrm{C}$ chronology for Upper Susquehanna Valley, but is the oldest so far obtained by Meadowood culture (Ritchie, 1969).

\section{I-6752. Loc 1, Feature 34}

$3350 \pm 95$

Feature seemed to pertain to Zone 7 , the deepest cultural level, which produced Lamoka-like points. Comment (REF): date conflicts with estimates for lowest level based on typologic crossties and other dates for Loc 1 . Since overlying sediments in this area had pinched out and were dipping toward an old beach line, the hearth may have been intrusive from Zone 2, Frost Island level.

\section{I-6753. Loc 2, Feature 16}

$\mathbf{3 2 0} \pm 100$

From Occupation 4, Early Owasco living floor. Comment (REF): date is late for this component. The odd shape of the hearth suggests disturbance by rodent activity, resulting in intrusion of very recent charcoal from a higher level.

\section{Kuhr 1 Site series, New York}

Hearth charcoal from Kuhr site, a stratified floodplain site in Otsego Co $\left(42^{\circ} 23^{\prime} 16^{\prime \prime} \mathrm{N}, 75^{\circ} 10^{\prime} 50^{\prime \prime} \mathrm{W}\right)$, New York. Coll 1972 by B Rippeteau and R Funk; subm 1972 by R Funk.

\section{I-6732. Feature 14}

$3880 \pm 155$

Feature from basal cultural level assoc with Normanskill type point. Comment (RF): date consistent with others for Normanskill points in Upper Susquehanna Valley.

\section{I-6733. Feature 71}

$3620 \pm 130$ $1670 \mathrm{BC}$

Feature from lower-middle level of site assoc with Snook Kill points. Comment (RF): date in line with stratigraphy of site, though older than single date available for Snook Kill site in Hudson Valley (Ritchie, 1969).

\section{I-6751. Feature 15}

$3500 \pm 105$

Feature from occupational level of Frost Island phase in middle levels of this site. Comment (RF): date consistent with other dates from site and similar components in Susquehanna, Delaware, and Senca drainages.

\section{I-6734. Kuhr 2 site, New York}

$3905 \pm 105$ $1955 \mathrm{BC}$

Charcoal from hearth in Zone $3\left(42^{\circ} 23^{\prime} 20^{\prime \prime} \mathrm{N}, 75^{\circ} 10^{\prime} 40^{\prime \prime} \mathrm{W}\right)$, Otsego Co, New York. Feature from Zone 3, an Archaic midden under- 
lying yellow-brown silt, capped by plow zone. Assoc with a Lamoka type point. Coll 1972 by R M Houck; subm 1972 by R E Funk. Comment (RF): date compatible for Lamoka point components.

I-6349. Otter Creek 2 site

$5070 \pm 210$

3120 BC

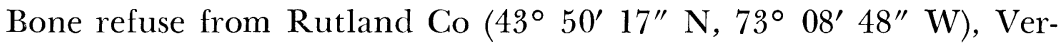
mont. Coll 1971 by W A Ritchie and R T Passino, subm by R E Funk, New York State Educ Dept, Albany. From basal midden assoc with artifacts of Vergennes phase of Laurentian tradition, including Otter Creek points, gouges ground slate points, and ulos. Comment (REF): 1st date for Vergennes component in New England; considered reliable based on typologic and stratigraphic data.

\section{Lewis-Walpole site series, Connecticut}

Charcoal from hearths at Lewis-Walpole site, E side of Pequabuck R $\left(41^{\circ} 42^{\prime} \mathrm{N}, 72^{\circ} 50^{\prime} \mathrm{W}\right)$, Farmington, Hartford Co, Connecticut. Coll 1972 and subm 1973 by D R Starbuck, Dept Anthropol, Yale Univ, New Haven, Connecticut.

\section{I-7187. 6-HT-15(a)}

$4130 \pm 90$

From Test Pit $30 \mathrm{~N} 15-16 \mathrm{E}, .20 \mathrm{~m}$ depth to surface of hearth.

\section{I-7188. 6-HT-15(b)}

$3960 \pm 90$

From Test Pit $30 \mathrm{~N} 2 \mathrm{E}, .35$ to $.40 \mathrm{~m}$ depth to surface of hearth. General Comment (DRS): dates pertain to Late Archaic period in Connecticut prehistory (Wilcox, 1967).

\section{Fourth of July Valley site series, Colorado}

Charcoal from Site 5BL120, N Fork Middle Boulder Creek $\left(40^{\circ} 00^{\prime}\right.$ $30^{\prime \prime} \mathrm{N}, 105^{\circ} 40^{\prime} 20^{\prime \prime} \mathrm{W}$ ), Boulder Creek Co, Colorado. Coll 1971 by B L Olson and subm 1971 by J B Benedict.

\section{I-6544. 5BL120-A}

$5880 \pm 120$

From fill of shallow-basin hearth, Grid Sq $2 \mathrm{~S} / 2 \mathrm{~W}$. Hearth dug in icecontact outwash on crest of Early Holocene terminal moraine, overlain by $8 \mathrm{~cm}$ loess.

\section{I-6545. 5BL120-B}

$6045 \pm 120$

From concentration in Grid Sq 1S/1W. Charcoal rested on ice-contact outwash, overlain by 11 to $14 \mathrm{~cm}$ loess.

General Comment (JBB): site is a hunting camp occupied by group transitional in development of McKean complex from Plano Progenitors (Benedict \& Olson, 1973). 


\section{Mount Albion series, Colorado}

Charcoal from Site 5BL67, E of summit of Mt Albion $\left(40^{\circ} 02^{\prime} 20^{\prime \prime} \mathrm{N}\right.$, $105^{\circ} 36^{\prime} 15^{\prime \prime} \mathrm{W}$ ), Boulder Co, Colorado. Alt 3500m.

I-3267. Mt Albion (a)

$$
\begin{aligned}
& 5800 \pm 125 \\
& 3850 \text { BC }
\end{aligned}
$$

From 13 to $18 \mathrm{~cm}$ depth in Grid Sq 8SW/8SE. Coll 1967 and subm 1968 by J B Benedict, Dept Sociol \& Anthropol, Colorado State Univ. Comment (JBB): date relates to occupation by Mt Albion complex (Benedict, 1970) during interval of soil formation in timberline region.

\section{I-3817. Mt Albion (b)}

$5730 \pm 130$

From 43 to $51 \mathrm{~cm}$ depth in Grid Sq 8SW/7SE. Coll 1968 by I Center, subm 1968 by J B Benedict. Comment (JBB): date relates to occupation of site by Mt Albion complex but was moved laterally and downward by early Neoglacial frost action.

\section{I-4418. Mt Albion (c)}

$5300 \pm 130$

\section{BC}

From 11 to $20 \mathrm{~cm}$ depth in Grid Sq 6SW/2SE. Assoc with Duncan projectile point in "Altithermal soil" zone. Coll and subm 1969 by J B Benedict. Comment (JBB): date applies to occupation of site by McKean complex during interval of soil formation in timberline region.

\section{Mount Albion (II) series, Colorado}

Charcoal from Site 5BL70, E of summit of Mt Albion $\left(40^{\circ} 02^{\prime} 20^{\prime \prime} \mathrm{N}\right.$, $\left.105^{\circ} 36^{\prime} 10^{\prime \prime} \mathrm{W}\right)$, Boulder Co, Colorado. Alt $3465 \mathrm{~m}$. Coll 1967 by J B Benedict and B L Olson; subm 1969 by J B Benedict.

\section{I-3023. II-A}

$$
5650 \pm 145
$$

$\mathbf{3 7 0 0 ~ B C}$

From upper of 2 charcoal layers at center of site. Comment (JBB): date applies to occupation of site by Mt Albion complex during interval of soil formation (Olson, 1969).

\section{I-3266. II-B}

$7650 \pm 190$

From lower of 2 charcoal layers at center of site. Comment (JBB): age is minimum for formation of turf-banked solifluction terrace at site (Olson, 1969).

I-4419. II-C

$5350 \pm 130$ $3400 \mathrm{BC}$

From $40 \mathrm{~cm}$ depth in circular, shallow-basin hearth, Grid Sq 1N/12W. Comment (JBB): date applies to occupation of site by Mt Albion complex (Olson, 1969).

\section{I-5449. Caribou Lake site, Colorado}

$8460 \pm 140$

Charcoal from Site 5 GA22, on inner slope of moraine damming Caribou Lake $\left(40^{\circ} 01^{\prime} 20^{\prime \prime} \mathrm{N}, 105^{\circ} 40^{\prime} 50^{\prime \prime} \mathrm{W}\right)$, Grand Co, Colorado. 
From 15 to $20 \mathrm{~cm}$ depth, Grid Sq $7 \mathrm{~S} / 2 \mathrm{E}$. Charcoal on upper of 2 till units separated by proglacial lake or beach sands, overlain by redeposited loess. Coll 1970 by I Asmus and J B Benedict; subm 1970 by J B Benedict. Comment (JBB): age is minimum for frost-sorting of upper till unit and applies to Cody complex component campsite at timberline (Benedict, 1973a).

\section{I-6616. Gamboa site}

Charcoal from large shell mound on Gamboa Ridge, NW1/4 SW1/4 sec 31 T21S R3E Lucia Quad ( $\left.36^{\circ} 04^{\prime} \mathrm{N}, 121^{\circ} 35^{\prime} \mathrm{W}\right)$, Monterey Co, Calif. From Trench $1,93 \mathrm{~cm}$ depth overlying sterile soil. Coll and subm 1972 by D M Howard, Monterey Archaeol Soc, Carmel. Comment (DMH): 1st date for an Esselen Indian site. The Esselen tribal group was a small member of Hokan linguistic stock from Santa Lucia Mts. Small side-notched bird points in site corroborates extension of site into historic times.

\section{I-6939. Presidio, CSU-SF 23}

$1210 \pm 85$

Human rib and vertebral bone from excavation beneath Bldg 628, US Army Presidio, San Francisco (37 $48^{\prime} 00^{\prime \prime} \mathrm{N}, 122^{\circ} 27^{\prime} 30^{\prime \prime} \mathrm{W}$ ), California. Coll and subm 1972 by R Heglar and M Moratto, Calif State Univ, San Francisco. Burial at depth $250 \mathrm{~cm}$ in brown sand. Comment (MM): dates an isolated Indian burial with a single cut and polished bird radius. No evidence of midden or occupational debris.

\section{B. Canada}

$445 \pm 85$

\section{I-6846. Sopher site (Bd Gu-1) Ontario, Canada}

AD 1505

Burned bark from ossuary lining at Sopher site Lot 2, Concession 1, S Orillia Twp, Simcoe Co $\left(44^{\circ} 37^{\prime}\right.$ N, $\left.79^{\circ} 29^{\prime} \mathrm{W}\right)$, Ontario, Canada. Coll 1962 and subm 1972 by W C Noble, Dept Anthropol, McMaster Univ, Hamilton, Ontario. Comment (WCN): site dated ca AD 1580 during early protohistoric period of $\mathrm{N}$ Huron development. Early protohistoric era in S Ontario believed to have commenced somewhat earlier (Noble, 1971).

\section{Bell House site series}

Charcoal from Bell site, $16 \mathrm{~km}$ NE of Lillooet, E bank of Fraser $\mathbf{R}$ $\left(50^{\circ} 44^{\prime} 35^{\prime \prime} \mathrm{N}, 121^{\circ} 49^{\prime} 30^{\prime \prime} \mathrm{W}\right)$, British Columbia. Coll 1971 by $\mathrm{M}$ Freisinger and J Dickin; subm 1971 by A H Stryd.

\section{I-6067. House 19-1}

$1515 \pm 90$

From Housepit 19, at depth $40 \mathrm{~cm}$, directly over only living floor. Assoc with developed Kamloops phase cultural material.

\section{I-6077. House 6-1}

$$
\begin{array}{r}
1590 \\
\text { AD 360 }
\end{array}
$$

From Housepit 6, depth $32 \mathrm{~cm}$, representing well defined charcoal 
stratum at youngest living floor in house. Assoc with cultural material immediately pre-dating Kamloops phase.

$$
\text { C. Mexico }
$$

\section{Rio Bec series, Campeche, Mexico}

Charcoal and wood from Rio Bec $\left(18^{\circ} 30^{\prime} 36^{\prime \prime} \mathrm{N}, 89^{\circ} 28^{\prime} 24^{\prime \prime} \mathrm{W}\right)$, Campeche, Mexico. Coll 1969 by $\mathrm{P}$ Thomas, J Eaton, and D Webster; subm 1970 by E Wyllys Andrews, 4th.

\section{I-4286. Becan, Structure IV, X-226}

$1230 \pm 95$

Charcoal from Structure IV, Rm 9, sealed between Floors 1 and 2. Assoc with ceramics of Chintok phase.

I-4287. Becan, Structure IV, X-230

$$
1295 \pm 95
$$

Charcoal from $\mathrm{Rm} 8$ in $8 \mathrm{~cm}$ fill representing final resurfacing. Comment (EWA): dates final construction of Structure IV.

\section{I-5024. Chicanna, Structure II, X-85}

$$
\begin{array}{r}
1280 \\
\text { AD } 670
\end{array}
$$

Charcoal from Structure II, $\mathrm{Rm} 1,95 \mathrm{~cm}$ below original $\mathrm{Rm}$ floor and fire-blackened wall stone. Comment (EWA): sample may have been assoc with dedicatory offering because wall stone appeared purposefully placed nearby a marine mollusk and other dedicatory offerings.

\section{I-5025. Chicanna, Structure II, X-6I}

$1265 \pm 95$

Sliver of lintel beam from $\mathrm{Rm} 1, \mathrm{~N}$ doorway $\mathrm{W}$ facade. Comment (EWA): building assoc with Chintok phase ceramics.

\section{I-5026. Chicanna, Structure XX, X-820-1}

$$
1380 \pm 95
$$

Wood from lintel beam of doorway. Assoc with Chintok phase ceramics.

\section{I-5027. Chicanna Structure XX, X-820-2}

$$
1230 \pm 95
$$

Wood fram vault stringer. Assoc with Chintok phase ceramics. Comment (EWA): stringer may be later replacement of an earlier wooden beam.

\section{I-5028. Becan, Structure XXV, X-719}

$1280 \pm 95$

Wood sealed under lowest floor of Structure XXV. Assoc with Bejuco phase ceramics.

\section{I-5029. Becan, Structure XXV-sub, X-737}

$$
1830 \pm 95
$$

\section{AD 120}

Charcoal sealed below floor of Structure XXV-sub. Comment (EWA): fill represents redeposit of earlier material of Pakluum phase and charcoal may date this earlier phase. Latest ceramics of this fill are of Sabucan phase. 
I-5030. Becan, Structure X, X-950

Wood from lintel beam of inner doorway, $\mathrm{N}$ facade. Building assoc with Acahual or Bejuco phase ceramics.

\section{Cadbury-Camelot series}

\section{Europe}

Cadbury-Camelot site is a multiple ramparted hillfort in S Cadbury $\left(51^{\circ} 01^{\prime} 30^{\prime \prime} \mathrm{N}, 02^{\circ} 31^{\prime} 30^{\prime \prime} \mathrm{W}\right)$, Somerset, England. Site occupation extended from Neolithic discontinuously to ca AD 1020. Coll and subm 1971 by L Alcock, Dept Archaeol, Univ Coll, Cardiff, Wales, United Kingdom.

\section{I-5970. SC/P 154B/2a}

$4460 \pm 120$

Deer antler from rock-cut Pit P154 on summit plateau of hill. Assoc with Neolithic pottery, animal bones, human mandible, flint flakes (Alcock, 1972). Comment (LA): date agrees with those of comparable pottery from other sites in Britain.

\section{I-5972. SC/P 154B/2b}

$4775 \pm 115$

Hazel nut shells from same location as I-5970.

\section{I-5971. SC/K 618}

$2875 \pm 90$ 925 BC

Ox bones from rock-cut ditch beside SW entrance through hillfort defences. Ditch filling was sealed by fossil soil underlying earliest iron age defenses of 6th-5th centuries BC. Comment (LA): stratigraphic position of ditch suggested a Neolithic age. However, no cultural material of this period could be recognized. Most probable explanation of ditch is as a boundary running tangentially to summit of hill.

\section{I-5973. $\mathrm{SC} / \mathrm{K} \quad \mathbf{5 3 0}$}

$$
2935 \pm 90
$$

985 BC

Deer antler beneath fossil soil sealed by earliest iron age defenses and above an apparent plough soil probably formed during Bronze age agricultural use of hilltop. Comment (LA): date compatible with stratigraphic position of sample and has helped clarify thinking about activity on hilltop before erection of earliest rampart.

\section{Franchthi Cave series}

Franchthi cave $\left(37^{\circ} 16^{\prime} \mathrm{N}, 23^{\circ} 8^{\prime} \mathrm{E}\right)$, is near $\mathrm{W}$ tip headland directly across bay from Kiolada in S Argolid, Peloponnese, Greece. Samples consist of charcoal mixed with cave sediment. Coll 1971 by S Diamant, B Legakis, L Watrous, N Price; subm 1971 by T W Jacobson, Indiana Univ, Bloomington (Jacobson, 1969; 1973). For additional dates for this site, see R, 1971, v 13, p 364-367; R, 1974, v 16, p 219-237; and R, 1975, v 17, p 201-203. 
I-6128. F/A Balk, Unit 120N

$6855 \pm 190$

4905 BC

From reddish brown sediment, $3 \mathrm{~m}$ depth. Represents transition from midclle to late Neolithic.

I-6129. Area H-1, Unit A175

$10,880 \pm 160$

8930 BC

From $6.45 \mathrm{~m}$ depth at top of shell midden, underlying MesolithicPaleolithic interface.

I-6139. Area H-1, Unit A173

$10,460 \pm 210$ 8510 BC

From $6.30 \mathrm{~m}$ depth in dark reddish soil. Directly above MesolithicPaleolithic interface.

\section{I-6140. Area H-1, Unit A219}

$22,330 \pm 1270$ 20,380 BC

From depth $8.80 \mathrm{~m}$ in dark red sediment assoc with heavy rockfall. Comment (TWJ): represents Upper Paleolithic, earliest date from site.

\section{E. Pacific Islands}

\section{Anuta Island series, British Solomon Islands}

Charcoal and carbonized endocarp of coconut (Cocos nucifera L) from stratified sand dune site, S coastal flats of Anuta I., Site BS-AN-6 $\left(11^{\circ} 40^{\prime} \mathrm{S}, 169^{\circ} 40^{\prime} \mathrm{E}\right)$, under present village of Rotoapi, British Solomon Is. Coll 1971 and subm 1972 by P V Kirch and P Rosendahl, Bernice Bishop Mus, Honolulu, Hawaii.

\section{I-6272. Bishop Museum ARC-1}

$$
2540 \pm 90
$$

From small hearth (Feature 3) near bottom of Layer III, in Excavation Area A, depth 150 to $169 \mathrm{~cm}$.

\section{I-6273. Bishop Museum ARC-2}

$$
390 \pm 90
$$

AD 560

From earth oven, Feature 9, near top of Layer II, in Excavation Area $\mathrm{B}$, depth 55 to $70 \mathrm{~cm}$. Comment (PVK): dates abandonment of site by $1 \mathrm{st}$ settlement population on Anuta I. Site was subsequently resettled by Polynesian population.

\section{I-6274. Bishop Museum ARC-3}

Rake-out material from earth oven, Feature 5, near top of Layer III, in Excavation Area C, depth 130 to $150 \mathrm{~cm}$.

\section{I-6275. Bishop Museum ARC-4}

$$
2830 \pm 90
$$

880 BC

From earth oven, Feature 7, near base of Layer III, in Excavation Area D, depth 125 to $135 \mathrm{~cm}$.

General Comment (PVK): age is estimate for initial occupation of Layer III at Site BS-AN6, and probably for initial occupation of Anuta I. The early assemblage of Layer III is characterized by plain pottery, one-piece 
Turbo shell fishhooks, and Tridacna shell adzes (Kirch \& Rosendahl, 1973a,b).

\section{Island of Lomlom series}

Charcoal from Site BS-RL-6, I. of Lomlom $\left(10^{\circ} 20^{\prime} \mathrm{S}, 166^{\circ} 15^{\prime} \mathrm{E}\right)$, British Solomon Is. Protectorate. Coll and subm 1971 by R C. Green.

\section{I-5749. BS-RL-6-C-3}

From Sq S-23, scattered charcoal from base of probable oven.

\section{I-6181. Ulawa, British Solomon Islands}

Charcoal from BS-UW-69-C-8, Loc CA 1, site of Ewewea, N of Lenga Village $\left(9^{\circ} 45^{\prime} \mathrm{S}, 161^{\circ} 55^{\prime} \mathrm{E}\right)$, British Solomon Is. Protectorate, E Dist, Ulawa. From test sq in small coastal mound, only one occupation layer. Coll and subm 1971 by G Hendron, Auckland Inst \& Mus, New Zealand. Comment $(\mathrm{GH})$ : assoc material indicates extensive chert tool manufacture and utilization, subsistence base not unlike that recorded at time of European contact.

\section{Island of Gawa series}

Charcoal from Site BS-RL-2, Reef I. Group (10²0 S, $\left.166^{\circ} 15^{\prime} \mathrm{E}\right)$, I. of Gawa, British Solomon Is. Protectorate. Coll and subm 1971 by R C Green, Auckland Inst \& Mus, Auckland, New Zealand.

\section{I-5747. BS-RL-2-C-1}

From Sq W-V26 in gray layer. Assoc pottery thought to be early Lapita tradition.

\section{I-5748. BS-RL-2-C-2}

From Sq W35-36, oven at base of black layer and into gray layer. Comment (RCG): anticipated ages of 2500 to $3000 \mathrm{yr}$ BP based on other Lapita dates in Oceania (Ambrose \& Green, 1972).

\section{San Cristobal, Pamua series}

Charcoal from Site BB-4-4, Pamua, San Cristobal $\left(10^{\circ} 21^{\prime} \mathrm{S}, 161^{\circ} 40^{\prime}\right.$ E), British Solomon Is. Protectorate. Coll and subm 1971 by R C Green.

\section{I-6176. BB-4-4-C-3}

From Sq N100-E95, 10 to $15 \mathrm{~cm}$ depth in floor.

\section{I-6177. BB-4-4-C-4}

$$
\begin{array}{r}
320 \\
\text { AD } 1630
\end{array}
$$

\section{AD 1590}

(irepit. Comment (RCG): Spanish pottery at this site is identical with that of Mendaña site at Graciosa Bay suggesting this is another settlement from the missing ship. These 2 samples support the conclusion with a pooled mean date of $1610 \pm 63$. 


\section{I-5750. BS-RL-6-C-4}

From $\mathrm{Sq}$ M-23 assoc with probable oven. Comment (RCG): pottery at this site thought to be later in Lapita tradition. Confirmed by polled mean age of $545 \pm 67$ вс.

\section{REFERENCES}

Alcock, L, 1972, Excavations at Cadbury-Camelot, 1966-1970: Antiquity, v XLV, no. 181, March, p 29-38.

Allen, J and Green, R C, 1972, Mendana 1595 and the fate of the lost Almiranta: an archaeological investigation: Jour Pacific History, v 7, p 22.

Ambrose, W R, and Green, R C, 1972, First millennium BC transport of obsidian from New Britain to Solomon Islands: Nature, v 237, p 31

Benedict, J B, 1970, Altithermal Occupation of the Front Range Alpine region: Abs, First Mtg Am Quaternary Assoc, p 8. no. 63 , p $1-4$. 1973b, Chronology of Cirque Glaciation in the Colorado Front Range: Quaternary Research, v 3, no. 4, p 584-599.

Benedict, J B, and Olson, B L, 1973, Origin of the McKean complex: evidence from Timberline: Plains Anthropol, pts 1-2, p 323-327.

Buckley, J D and Willis, E H, 1969, Isotopes' radiocarbon measurements VII: Radiocarbon, v 11, p 53-105.

Calkin, P E, 1970, Strand Lines and chronology of the glacial Great Lakes in NW New York: Ohio Jour Sci, v 70, no. 2, p 78-96.

Calkin, P E and McAndrews, J H, 1969, Dating late glacial recession and vegetation in the Erie basin: NW New York Geol Soc America abs with programs for 1969, pt 1, p 5 .

Funk, R E, Rippeteau, B E, and Houck, R M, 1973, A preliminary cultural framework for the Upper Susquehanna Valley: New York State Archeol Assoc Bull, no. 57, p 11-27, Rochester.

Gfeller, C, Oeschger, H, and Schwarz, U, 1961, Bern radiocarbon dates I: R, v 3, p 15-25.

Jacobson, T W, 1969, Excavation at Porto Cheli and vicinity: preliminary rept II: The Franchthi Cave, 1967-1968: Hesperia, v 38, no. 3, p 343-381. p $45-88$. 1973, Excavations in the Franchthi Cave, 1969-1971: Hesperia, v 42, no. 1 ,

Kirch, P V and Rosendahl, R, 1973a, Notes on radiocarbon dates for pottery bearing layers on Anuta I: Polynesian Soc Jour, June, p 12.

1973b, Archaeological investigations of Anuta-a polynesian outlier in the Solomon Islands: Pacific Anthropol Recs, v 21, p 35-50, Honolulu.

Lasalle, P and Chagnon, J, 1968, An ancient landslide along the Saguenay River, Quebec: Can Jour Earth Sci, v 5, no. 3, p 548-549.

Mickelson, D M and Borns, H W, Jr, 1972, Chronology of a Kettlehole Peat Bog, Cherryfield, Maine: Geol Soc America Bull, v 83, p 827-832.

Noble, W C, 1971, The Sopher Celt: an indicator of Early Protohistoric trade in Huronia: Ontario Archaeol, v 16, p 42-47, Toronto.

Olson, B L, 1969, An Archaic site in the Colorado Front Range (abs): ColoradoWyoming Acad Sci Jour, v 6, p 43.

Ritchie, R A, 1969, The archaeology of New York State, 2nd ed: Natural History Press, New York.

Sears, P B, 1967, The Castalia Prairie: Ohio Jour Sci, v 67, no. 2, p 78.

Stauffer, P H, 1971, Quaternary volcanic ash at Apang, Kuala Lumpur, West Malaysia: Newsletter Geol Soc, Malaysia, v 33, p 5-8.

Vita-Finzi, C, 1974, Age of valley deposits in Perigord: Nature, v 250, p 568-569.

Wilcox, U V, III, 1967, The Lewis-Walpole site of Farmington, Connecticut, a preliminary rept: Archaeol Soc Connecticut Bull, no. 35.

Yerkes, R J, Bonilla, M G, Youd, L T and Sims, J D, 1973, Geologic environment of the Van Norman Reservoirs, San Fernando, California: US Geol Survey open file rept, units 1-4. 